\title{
INTERNATIONAL FRANCHISE AGREEMENT
}

\author{
Bohdan Stetsiuk', Yurii Miroshnychenko², Pavlo Dudko
}

\begin{abstract}
The purpose of the article is to study the legal nature of the international franchise agreement, its types, essential conditions and peculiarities of its conclusion. The subject of the study is the international franchise agreement. Research methodology. The research is based on the use of general scientific and special-scientific methods and methods of scientific knowledge. The dialectical method allowed investigating the definition of the international franchise agreement and its essential conditions. The comparative legal method was used to compare doctrinal approaches to this issue. Interpretation of the content of international legal acts governing issues related to the conclusion of the international franchise agreement was realized with the help of the normative-dogmatic method. The system-structural method is used to study the international franchise agreement as a single whole (system) with the coordinated functioning of all its elements. The methods of grouping and classifying formed the basis for separating the list of conditions, which are necessary for the conclusion of this contract, as well as the provisions that should be included in the content of the agreement. Methods of analysis and synthesis helped to study some parts of this agreement to formulate further conclusions. Practical implication. The analysed recommendations of scientists and lawyers, as well as the provisions of international regulations, can be used when concluding an international franchise contract. Correlation/originality. The scientific novelty of the work consists of an integrated approach to the study of theoretical and practical issues related to the international franchise agreement.
\end{abstract}

Key words: international franchising, international franchise agreement, franchise, essential conditions, international organizations, model contracts, general recommendations.

JEL Classification: F13, F16

\section{Introduction}

International franchising becomes very important under present-day conditions. Over the last decade, it has become a popular format for doing business in various sectors of the economy, and small and medium enterprises have been using it to expand their business for over 100 years. At present, a large number of successful companies create franchising companies in other countries. Franchising has been a driving force for economic development, one of the main channels for sale of goods and services in many states, and its prevalence in a wide variety of industries clearly demonstrates the high degree of its efficiency. The system of international franchising creates favourable conditions for companies to enter the domestic markets of other countries and stimulates the rapid development of entrepreneurial activity.

The research on the development of franchising as a form of international business was conducted by such native scientists as T. M. Hryhorenko, O. Ye. Kuzmin, A. M. Mahomedova, V. Ye. Sakharov, T. M. Tsyhankova, A. V. Tsyrat, I. M. Shkola. Among the foreign scientists, special attention to this issue

\footnotetext{
Corresponding author:

${ }^{1}$ Lviv Polytechnic National University, Ukraine.

${ }^{2}$ Volodymyr the Great Educational and Scientific Institute of Law

Interregional Academy of Personnel Management, Ukraine.

${ }^{3}$ Kyiv National University of Technologies and Design, Ukraine.
}

paid by V. V. Bezbakh, K. M. Bielikova, V. A. Bielov, N. H. Vilkova, T. M. Hryhorenko, Zh. Deltei, I. S. Zykin, V. B. Korzun, P. Kotler, M. Mendelson, A. Panfilova T. V. Syniavska, D. P. Stryhunova, Ya. I. Funk.

In this scientific work, we will consider the definition of the international franchise agreement, as well as its types, clarify the legal nature of this contract and establish its essential conditions. In addition, we will study the international legal acts regulating this issue, the views of scientists and lawyers on the issue of regulation of the international franchise agreement, and analyse the main recommendations of lawyers for the conclusion of this agreement.

\section{Statement of the baseline}

Some scholars affirm that franchising originated in the Middle Ages (Nykoliuk, 2009), however, it is well-known that the first franchise of the model which is currently in use appeared at the beginning of the 20th century. This format of this franchise was developed by Singer Sewing Machine Company in the USA, which established a network of servicing for its sewing machines. 
In the 1950s, the interest in franchising was growing significantly; its concept was taken over by an increasing number of enterprises in various sectors of the economy. In 1960, the International Franchising Association (IFA) was established in Washington (USA) to protect and promote the interests of the franchising industry. In 1972, the European Franchise Federation (EFF) was founded to regulate issues related to franchising in Europe. In 1990, this Federation made the European Code of Ethics for Franchising, on which the regulation of franchising relations in each European state is based.

In the XXI century, we are witnessing a further increase in the number of franchise business owners who are looking for new territories and opportunities to promote their networks. The access to international markets allows the franchisor to set up their businesses in other countries. Such a model of entrepreneurial activity helps to establish relations between states, as well as contributes to the development of the economy. Therefore, there is a rapid growth of international franchising not only in Europe but also in CIS countries.

International franchising has a number of significant advantages such as: 1) an exploitation of local management personnel may help to overcome the problem of foreign language and culture; 2 ) on account of impossibility or high value of proper control at a distance, business supervision is entrusted to a local specialist; 3) the necessary legal procedures are implemented by local lawyers, what allows the lawful sale of goods in the target country without any liability under its legislation; 4) the possibility of avoiding laws of certain countries which prohibit or control the income of foreign direct investment; 5) the ability to overcome political difficulties, such as, for example, the possibility of expropriation of foreign direct investment. The franchisee, as a rule, is a resident of the target country, and therefore, the risk of such a problem is significantly reduced. In any case, even if the property is expropriated, the franchisee will suffer losses, not the franchisor; 6) one of the biggest advantages of international franchising is the possibility of avoiding tariff imposts, which, in spite of a large number of international agreements, still hamper the development of the world trade (Warren Pengilley).

The essence of international franchising is that the franchisor (the franchise owner) gives the franchisee (the franchise buyer) the right to represent its own brand on the international market. In this, the franchisee can use the trademark, as well as know-how, technology and business model as a whole. All rights and obligations of the parties are registered in the relevant contract - the international franchise agreement.

As evidenced by the foregoing, the question of legal regulation of this agreement becomes more and more relevant because, despite the fact that it is used in more than 80 countries of the world, the unification of this institute has never happened in the international legal scene. As it was correctly noted in the scientific work by H. Braun, “... only since World War II and increasingly in the past ten years has franchising achieved recognition as a distinct method of marketing ... [but] ... there is no generally accepted definition of franchising in court decisions, regulation or legislation. Further, any definition would fail to include the many functions inherent in the system, as well as its potential for abuse..." (Brown, 1972).

Consequently, as it was already mentioned, at present there is no generally accepted definition of an international franchise agreement. From the standpoint of private law, a franchise agreement is international if it is concerned with law and order of two or more states, that is, in cases when the parties to the contract - the franchisor and the franchisee - have their principal places of business (commercial enterprises) in territories of different countries. A franchise agreement, including an international one, is a kind of commercial agreement since its parties are legal entities engaged in entrepreneurial activity (Stryhunova, 2014).

In the specialized literature, one can find the following definition of the international franchise agreement:

1) it is a special type of license agreement on the transfer of intellectual property rights. In accordance with this agreement, the licensor (franchisor) issues a license to a foreign licensee (franchisee) to conduct certain business operations under the name of the licensor. Under the conditions of a franchise agreement, licenses for the use of such subjects of industrial property as methods of entrepreneurial activity (know-how), trademarks (service marks) of the franchisor are often transferred to the franchisee, as well as technical and commercial assistance is provided. A franchise license is often issued in exchange for direct (royalty) or indirect financial compensation (counter service, etc.), and usually provides for the franchisor to receive remuneration during the term of the contract. As a rule, under a franchise contract, the licensor has the right to exercise strict control over the franchisee's authorized activity during the term of the license (Mezhdunarodnye franchaizynhovye kontrakty).

2) It also defined as a contract whereby the franchisor grants the franchisee (based in another country), in exchange for direct or indirect financial compensation, the right to exploit a package of industrial or intellectual property rights relating mainly to know-how and commercial symbols, and to receive continuing commercial or technical assistance for the duration of the contract. International franchise agreements may regard distribution of goods or supply of services. In distribution franchise agreements, the franchisee is granted the right to market the products manufactured or supplied by the franchisor or by a supplier designated by the franchisor, under the franchisor's trademark according to the franchisor's commercial know-how and with its commercial assistance. In service franchise 
agreements, the franchisee is granted the right to provide services (e.g. restaurants, hotels etc.) developed by the franchisor, under the franchisor's trademark according to the franchisor's commercial know-how and with its commercial assistance (Llamazares).

In addition, the following types of international franchise agreements are also distinguished depending on the type of activity:

- manufacturing franchise agreement: according to this agreement know-how in the form of manufacturing technique and technical experience of the franchisor is transferred. A franchisee can make products of the same quality and characteristic as the franchisor in his production area. The agreement allows the franchisee to put on a trademark owned by the franchisor on the manufactured goods, as well as to sell the manufactured products;

- business-format franchise agreement: the franchisee receives not only the right to sell goods/services and the methodology of sales or services provision (as it is provided for product distribution franchising) but also the whole business concept starting from the sales outlet design, staff uniform, customer service, personnel training to recommendations on promotion and marketing);

- mixed franchise agreement is based on a combination of the main types of franchise agreements: product, service and manufacturing. Under this contract, the franchisor producers and the franchisee sells these goods through its franchise point and at the same time provides services related to the use of these products;

- product distribution franchise agreement - under this contract the franchisee has the right to sell the range of goods or to provide a list of services under the franchisor's trademark (Vydy franchaizynha).

The main sources of legal regulation of the international franchise agreement are a national law and so-called "lex mercatoria". National law applies to an international franchise agreement by virtue of the autonomy of will of the parties or by virtue of the law applicable in the absence of an agreement between the parties on applicable law. Lex mercatoria is an autonomous legal order, which is formed voluntarily by the parties involved in international economic relations and which exists independently of national legal systems. This set of rules is used as an alternative to the national law applicable in a particular case.

Such influential international organizations as the International Institute for the Unification of Private Law (UNIDROIT), the World Intellectual Property Organization (WIPO), the International Chamber of Commerce (ICC) have repeatedly tried to define the franchise agreement in general and the international franchise agreement in particular, as well as to establish common rules for its regulation.

Thus, in 2007, the UNIDROIT issued the 2nd edition of the Guide to International Master
Franchise Agreements (UNIDROIT). It provides a comprehensive examination of the whole life of this type of arrangement, from the negotiation and drafting of the master franchise agreement and other associated agreements to the end of the relationship. It deals principally with the positions of the parties directly involved, i.e. the franchisor and the sub-franchisor but, in instances where it is considered to be of particular importance, the positions of others affected, such as sub-franchisees, are covered.

In 1994, the WIPO published the Franchising Guide (World Intellectual Property Organization). Paragraph 4 of this Handbook states that "from a legal standpoint, franchising relies on contract law and, therefore, does not necessarily require any special regulatory or legislative structure in order to function and develop. It is, therefore, appropriate to stress at the outset that no specific regulation of franchising has been or would be necessary for franchises to thrive in any economy. However, some governments have nevertheless chosen to adopt legislation to regulate franchising. Overregulation could, however, have the effect of discouraging investment in this area”.

Nevertheless, Section V of the Guide is devoted to the typical terms of a franchise agreement, such as: rights and obligations of the franchisor and the franchisee, payment arrangements, compliance with quality control requirements; provisions on breach of contract; renewal of contract, etc., and Appendix II to the Guide provides an overview of the intellectual property rights typically included in franchise agreement.

In 2000, the ICC developed the Model Contract for International Franchising (The ICC Model International Franchise Contract, 2000, the publication of ICC № 557). It is the typical contract aimed at promoting goods, which contains uniform rules, recommended by the ICC to the participants in these legal relations. When creating a model contract, the drafters intended to foresee the fundamental rights and obligations of the parties and to avoid application of the national law of any country. The main reason for this contract is the lack of international unification of franchising and the necessity to appeal to domestic law, what would involve disadvantages, as the law of individual states does not take into account the needs and specifics of international trade, and its regulations vary considerably in individual countries. The rules agreed at the international level (first of all in the EU), mainly affect the antitrust aspects of the contract (for example, the effect of certain restrictive provisions on the exclusivity of the territory) and do not regulate the civil matters of the parties to the franchise agreement (Vylkova, 2002).

In 2011, the ICC Model International Franchise Contract № 557 was reviewed and completed to provide users with updated information on issues related to antitrust laws and regulations governing franchising relationships. The 2 nd edition of the ICCModel Contract 
(ICC Publication № 712 E) (International Chamber of Commerce) offers franchisors and franchisees flexible formulations of solutions that accurately meet business needs, for legal certainty and compliance general application practice. In order to ensure clarity and use facility, an explanatory comment has been added to the contract, which provides alternative drafting options and hints for identifying potential legal traps.

However, as indicates V. A. Bielov, typical or, in other words, model ICC Contracts can hardly be called the acts of international private unification in the literal sense of the word. Despite their name "typical", they are purely advisory, and the practice of their application is based solely on the professional authority of the developer. Since they are made not in relation to some particular cases of foreign trade operations, but in general, typical contracts have such content, which is called "balanced" and free from the conjuncture. Balance means an equal degree of concern for the interests of both parties, and freedom from the conjuncture is an assessment of these interests from the point of view of a competent, intelligent, fair and impartial observer. In this respect, they are similar to the acts of private unification.

At the same time, it is obvious that the texts of typical contracts cannot in any way become texts of specific contracts without at least minimal adaptation to the features of particular situations and conditions of these agreements. In other words, the norms contained in model contracts are not figured for general application, whatever it would be executed - directly or through the implementation of their provisions to national legislation. This is the main content difference between the ICC Model Contacts and the acts of private legal international unification (Belov, 2014).

The same opinion is followed by K.E. Zwisler. The main problem associated with the model franchise contract, according to the scientist, is its goal - an attempt to provide a single solution to all issues, although sometimes alternative provision is offered. It is designed to meet the needs of all franchise operations in all cases. However, the desire to work out a single solution for most of the issues that arise when concluding an international franchise agreement is not a realistic goal, as the author considers.

That decision may cause the model to be more of a problem than a blessing for new international franchisors and international franchise lawyers. Anyone who has got experience in this field knows that a good franchise agreement must reflect scores of business and legal decisions that make each franchise unique. Those lawyers who regularly advise international franchisors know that typical contracts are only an imperfect starting point when concluding franchise agreements for new clients. Dozens of hours of work are usually required to adapt these model contracts to the needs of each individual franchisor client (Carl E. Zwisler).

However, lawyers with many years of experience in this field have made general recommendations for the conclusion of an international franchise agreement, by which one should be guided. So let's consider some of them.

Consequently, the most important point of negotiation in international franchise agreements is the negotiation of the initial document, which is usually a Master Franchise Agreement. As it was already mentioned, this issue is comprehensively regulated by the Guide to International Master Franchise Arrangements (UNIDROIT). In accordance with Clause 1 of this Guide in master franchise agreements, the franchisor grants another person, the sub-franchisor, the right, which in most cases will be exclusive, to grant franchises to sub-franchisees within a certain territory (such as a country) and/or to open franchise outlets itself. The sub-franchisor, in other words, acts as a franchisor in the foreign country. The sub-franchisor pays the franchisor financial compensation for this right. This compensation often takes the form of an initial fee, which may take any one of a variety of different forms, and/or royalties constituting a percentage of the income the subfranchisor receives from the sub-franchised outlets. In master franchise arrangements, essentially two agreements are involved: an international agreement between the franchisor and the sub-franchisor (the master franchise agreement), and a domestic franchise agreement between the sub-franchisor and each of the sub-franchisees (the sub-franchise agreement).

There are other types of initial international franchise agreements, depending on the way of organizing the trading network. Thus, international franchising can be done through: direct (unit) franchise; branch office or subsidiary; area representative; joint venture. Let's briefly consider each of them: a) direct (unit) franchising. This is a cooperation agreement between two legally independent parties (franchisor and franchisee) located in different countries. The franchisor provides the franchisee with the exclusive right to distribute its products or services in establishments, which are equivalently equipped and furnished, as well as the right to use intellectual property rights (commercial signs, brands, trademarks etc.). It also provides the know-how (Franchise Handbook), and the technical and commercial support for distribution to be carried out correctly. Since the expenses for international network supervision from a single centre could be very significant, it is recommended to conclude direct franchise agreements only if the target country is geographically, culturally, linguistically and/or legally similar to the franchisor's country; b) establishment of a branch office or a subsidiary in the target country. The advantage of this type of franchise is that the franchisor can directly control the franchisee in the target country. A disadvantage is the possibility of losing the benefits of the franchising concept by having to establish subsidiaries in a wide variety of foreign countries. As an alternative, a joint venture may be established between the franchisor and the local enterprise; $c$ ) a joint venture 
agreement. The decision on a joint venture necessarily involves the physical presence of the franchisor in the target country. The main advantage of a joint venture is that the financial risk of the parties is shared. However, not infrequently equal representation on boards and equal shareholdings may lead to the emergence of corporate problems, as well as problems with the foreign investment if there are relevant restrictive laws in the target country. In addition, the joint venture involves very active and continuous participation of the franchisor in the project. Joint ventures and subsidiaries are the forms of international franchising commonly used by many fast food companies; d) under area representation agreement. Area representative acts as a mediator between the franchisor and the franchisee. Unlike the master franchisor, the area representative does not act on his own behalf, but on behalf of and for the benefit of the franchisor. The main responsibilities of the area representative are the selection of potential candidates for the franchisor, their evaluation and communication with them, as well as providing certain services to unit franchisees within its designated territory, such as training, site selection, grand opening assistance and on-going support. However, if the representative is not able to cope with the obligations imposed on him, the negative result of this will affect all departments in the territory committed to him. Another possible problem is the tendency that has arisen among regional representatives, to hire salaried managers for each separate branch (Warren Pengilley; Llamazares).

After the Master Franchise Agreement (or other primary agreement) has been negotiated, the basic rules for parties are established. Further agreements will depend upon the initial document. If it is not properly negotiated, there for sure will be considerable problems with the conclusion of following agreements. Thus, the primary contract is the most important because of its influence on subsequent agreements. It is necessary to take into account even the smallest details and to pay special attention to seemingly insignificant issues, because, as a rule, over their imperfect study there might be significant gaps in the content of the contract.

When concluding an international franchise agreement, the parties need to consider a number of issues that will help them to establish effective cooperation.

The main issues are the following: 1) what is being franchised? 2) what are the franchisor's obligations? 3 ) what are the franchisee's obligations? 4) what marks, including logos and patents, are involved and what is their legal status? 5) what is the length of the franchise? 6) what exclusivity provisions (product, territorial, or customer) are applicable? 7) What are to be the payment arrangements? Is payment:

- "up front", based upon a royalty, or a combination of both? - subject to minimum royalties? - to be made in the franchisor's currency, the franchisee's currency, or a third currency? • to be subject to agreed limitations on exchange rate variations? - to be made exclusive, inclusive or otherwise of certain taxes and the impost of the target country? • to be made monthly, quarterly, semi-annually, or at other designated times? 8) are there minimum performance provisions? 9) what competition restraints (during the agreement and after termination) will exist? 10) are there to be any "buy out" or "buy back" options? 11) what provisions apply relating to choice of law? (Warren Pengilley).

The key elements of the international franchise agreement vary for each of its parties. Thus, for franchisor they are as follows: a) the licensing of knowhow embodied in operational manuals and continuously updated, with a training support system; b) the licensing of trademarks and symbols; c) the provision of assistance regarding distribution and management.

For a franchisee: a) the franchisor's exercise of reasonable quality controls over the franchisee to protect its intellectual property rights; b) the payment of initial and ongoing fees in exchange for the right to use these intangible assets; c) the participation in training courses organized by the franchisor; $d$ ) the use of franchisor's trademarks and symbols; e) the strict compliance with the franchisor's commercial standards; f) the information given to the franchisor concerning any difficulty which may appear or improvements which may seem suitable.

For both parties: a system to resolve disputes, including the service of notice of defaults and opportunities to cure (Llamazares).

Consequently, based on the aforesaid, we can conclude that the essential conditions of the international franchise agreement are: 1) know-how, which includes any confidential, valuable information that is the property of the firm, experience and methods of work of the franchisor, which enable the franchisee to repeat his success. It also includes the commercial and technical support of the franchisor and trainings he organizes for the franchisee. In exchange, the franchisee obliges not to violate the franchisor's intellectual property rights and to take all possible measures to protect confidential data; 2) commercialname, trademarks and patents. Recognition of customers and their confidence in products and services are usually associated with a trademark, which is one of the key elements of the success of the franchise network. Franchisee agrees that the franchisor is entitled to all intellectual property rights, and the franchisor, in turn, has the right to control the quality of the goods (services) produced (provided) by the franchisee; 3) products and territory. A clear definition of products and distribution areas are very important for achieving quality standards and for providing the franchisee with the ability to maintain a stock of goods in order to meet the needs of customers and comply with sales or sales requirements in an exclusive area where it is a separate and independent entity; 4) payment of fees and royalties. The parties must determine precisely the method and time of 
payment, taking into account the fact that there are many options for calculating royalties. Non-payment of royalties may be considered as a violation of the contract and lead to the emergence of the right to terminate the contract; $5)$ the term of validity and renew of the contract. The parties may conclude a contract for a definite or indefinite period. One should carefully consider the conditions, under which the contract may be prolonged, renewed or terminated, as well as the consequences of such actions.

\section{Conclusion}

So, as a summary, it should be noted that, because of significant development of franchising in the international arena, the issue of regulation of an international franchise agreement is becoming increasingly relevant. At present, there is no standardized definition of the international franchise agreement, as well as a legal framework for its regulation, therefore, national law and the norms of the so-called "lex mercatoria" are responsible for its legal adjustment.

Experienced international lawyers, as well as by such wellknown and authoritative organizations as UNIDROIT, WIPO, ICC have made attempts to define the international franchise agreement and to settle this institution. The ICC Model International Franchise Contract, which was made by ICC members and is currently widely used in international practice, offers franchisors and franchisees flexible formulations of solutions that precisely meet business needs. However, many scholars believe that the norms contained in model contracts are not designed for a common, uniform application without at least minimal adaptation to the features of particular situations and conditions of these agreements.

Therefore, specialists in the field of international franchising have developed general recommendations that could be used for the conclusion of this agreement. Among other things, they provide pieces of advice concerning the determination of the legal nature of the franchise agreement, the key points that are worth to be noticed, the essential conditions that must be foreseen, and the ways to avoid possible legal traps. When negotiating on the conclusion of an international franchise agreement, it is proposed to involve a specialist who has a long experience in this field and who will be able to choose the type of contract that meets all the requirements of the client and to adapt the provisions of the future agreement to its needs.

\section{References:}

Nykoliuk, V. V. (2009). Pravovoe rehulyrovanye dohovora mezhdunarodnoho franchaizynha: ucheb. posobye [Legal regulation of international franchise agreement: study guide]. Omsk: Omskaia akademyia MVD Rossyy.

Warren Pengilley. International franchising arrangements and problems in their negotiation. Northwestern Journal of International Law \& Business, 7 (2), 185-207.

Brown, H. (1972). Franchising remedies and realities. URL: https://scholarlycommons.law.northwestern.edu/ cgi/viewcontent.cgi article $=1196 \&$ context $=$ njilb

Stryhunova, D. P. (2014). Dohovor mezhdunarodnoho franchaizynha [International franchise agreement]. Sovremennoe pravo, 12, 135-142. URL: https://www.sovremennoepravo.ru/m/articles

Mezhdunarodnye franchaizynhovye kontrakty [International franchise contracts]. International Franchise Agreements. URL: https://www.miripravo.ru/contract/intellect/franchising/index.htm

Llamazares, O. International franchise agreement: key elements and types. International Contracts Comments. URL: https://www.globalnegotiator.com/blog en/international-franchise-agreement-template-model/

Vydy franchaizynha [Types of franchising]. URL: http://franchisinginfo.ru/franchayzing/4/vidy-franchayzinga

UNIDROIT. Guide to International Master Franchise Arrangements (Second edition). International Institute for the Unification of Private Law (UNIDROIT). Rome, 2007. URL: https://www.unidroit.org/english/ guides/2007franchising/franchising2007-guide-2nd-e.pdf

World Intellectual Property Organization (WIPO). Franchising Guide. International Bureau of WIPO. Geneva, 1994. URL: ftp://ftp.wipo.int/pub/library/ebooks/wipopublications/wipo_pub_480(e).pdf

Vylkova, N. H. (2002). Dohovornoe pravo v mezhdunarodnom oborote [Contract law in international circulation]. M.: Statut.

International Chamber of Commerce. ICC Model International Franchising Contract. ICC Publication № $712 \mathrm{E}$. URL: http://store.iccwbo.org/content/uploaded/pdf/ICC-Model-International-Franchising-Contract.pdf

Belov, V. A. (2014). Mezhdunarodnoe torhovoe pravo y pravo VTO. Poniatye y ystochnyky. Obychay. Mezhdunarodnye dohovory: uchebnyk [International contract law and WTO law. Concept and sources. Practice. International agreements: textbook]. M.: Yzdatelstvo Yurait.

Carl E. Zwisler. Amended ICC Model International Franchise Contract is Problematic for Franchising. Franchising World, 2011. URL: https://www.franchise.org/amended-icc-model-international-franchise-contractis-problematic-for-franchising 